\title{
PKM di Perum Puri Kelapa Gading Paniki Atas, Talawaan, Minahasa Utara, Sulawesi Utara Tentang Edukasi Mencegah Penyebaran Covid-19
}

\author{
Hosea Jaya Edy ${ }^{1 *}$, Imam Jayanto ${ }^{1}$ \\ ${ }^{1}$ Program Studi Farmasi, Fakultas Matematika dan Ilmu Pengetahuan Alam, \\ Universitas Sam Ratulangi Manado, 95115, Sulawesi Utara, Indonesia \\ *Penulis korespondensi. Email : hosea_tob@yahoo.com
}

\begin{abstract}
ABSTRAK
Covid-19 merupakan penyakit menular yang bermula dari Wuhan, China. Sekitar lebih dari 200 negara di dunia terjangkit virus covid-19 dan banyak menimbulkan korban jiwa dalam waktu yang sangat cepat. Pemerintah melakukan pembatasan kegiatan masyarakat sebagai upaya memutus mata rantai penyebaran virus covid-19. Pencegahan penyebaran penyakit menular tersebut harus segera dilakukan dengan tepat. Metode yang dilakukan adalah Kampanye Informasi Edukasi (KIE) kepada warga agar terhindar dari penularan Covid-19. Edukasi yang diberikan adalah himbauan untuk mengenakan masker, mencuci tangan dan menjaga jarak sosial. Hasil dari KIE dalam rangka pencegahan Covid-19 di Perum Puri Kelapa Gading adalah peningkatan kesadaran warga untuk mengenakan masker sebesar $68 \%$ untuk warga yang mengendarai mobil, $40 \%$ untuk warga yang mengendarai motor dan meningkat $150 \%$ bagi warga yang berjalan kaki. Edukasi dan bantuan yang diberikan mampu memberikan solusi bagi warga Puri Kelapa Gading untuk menjaga diri dari paparan Covid-19.
\end{abstract}

Kata kunci : Covid-19, Masker, Mencuci tangan, Menjaga jarak sosial.

\begin{abstract}
Covid-19 is a contagious disease, which originated in Wuhan City of China. Nearly 200 countries in the world are infected with the covid-19 virus and claiming thousands of human lives in a short time. Government policy to lockdown was needed, as an effort to break the chain of the spread of the Covid-19 virus. The prevention of infectious diseases must be done immediately. The method used is an educational information campaign (IEC) for residents to avoid Covid-19 transmission. The education provided was an appeal to wear masks, wash hands and maintain social distancing. The result of the IEC in the context of preventing Covid-19 at Perum Puri Kelapa Gading was an increase in residents' awareness of wearing masks by $68 \%$ for residents who drive cars, $40 \%$ for residents who ride motorbikes and an increase of $150 \%$ for residents who walk. The education and assistance provided are able to provide solutions for residents of Puri Kelapa Gading to protect themselves from exposure to Covid-19.
\end{abstract}

Key words : Covid-19, Mask, Washing hands, Social distancing. 


\section{PENDAHULUAN \\ Analisis Situasi}

Virus covid-19 sangat membuat resah masyarakat dunia pada tahun 2020 ini dengan wabah penyakit covid-19. Pandemi atau wabah covid-19 sangat mengganggu aktivitas masyarakat disegala bidang dan sudah banyak menimbulkan korban jiwa. Virus covid-19 merupakan bagian dari family Orthocronavirinae, keluarga Covid19 viridae dan ordo Nidovirales. Beberapa penyakit yang dapat disebabkan oleh virus golongan ini adalah ISPA, SARS, MERS dan COVID 19 (Telaumbanua, 2020; Yunus dan Rezki, 2020).

Penyakit covid-19 dapat menginfeksi tanpa memberikan gejala klinis, sehingga penderita tidak merasakan perubahan dalam dirinya. Beberapa gejala klinis yang dirasakan mulai dari flu biasa, batuk dan pilek. Gejala klinis yang lebih berat seperti demam tinggi, nyeri tenggorokan, nyeri otot, kehilangan indra pembau dan perasa, sesak nafas hingga menyebabkan kematian (Huang dkk, 2020; Chen dkk, 2020).

Droplet atau percikan air liur yang keluar dari mulut merupakan salah satu media penyebaran virus covid-19. Droplet membawa virus dari dalam tubuh orang yang terinfeksi virus covid-19 ketika berbicara, bersin maupun batuk. Kontak fisik juga dapat menyebabkan penyebaran virus covid-19 seperti bersentuhan dan berjabat tangan. Kontak fisik tersebut akan memindahkan virus dari penderita kepada orang lain (Singhal, 2020 ; Zukmadini dkk, 2020).

Virus covid-19 menyebar dengan sangat cepat dan menginfeksi banyak manusia yang terpapar virus tersebut. Kasus infeksi virus covid-19 di Indonesia maupun di dunia meningkat sangat cepat dengan korban jiwa yang cukup besar. Penanganan pencegahan penyebaran virus juga harus dilakukan secara masif dan serentak di segala penjuru dunia. Pemerintah sudah melakukan penanganan penyembuhan terhadap pasien yang terinfeksi virus covid19. Masyakat pada umumnya juga harus aktif mencegah penyebaran virus dengan berbagai cara dan metode yang tepat (Mona, 2020).

Pengabdian kali ini dilakukan guna memberikan edukasi kepada masyarakat untuk secara aktif mencegah penyebaran virus covid-19. Perilaku Hidup Bersih dan Sehat atau lebih dikenal dengan istilah PHBS sangat berperan dalam membantu mencegah penyebaran virus covid-19 (Razi dkk, 2020). Beberapa hal yang sangat penting dilakukan adalah memakai masker dengan baik dan benar akan membantu mencegah penyebaran droplet yang mengandung virus covid-19. Masker juga membantu mencegah terhirupnya virus yang terbawa dalam droplet penderita covid 19. Edukasi untuk rajin mencuci tangan mengunakan sabun dan air mengalir juga sangat penting untuk membunuh kuman yang melekat pada tangan dan jari. Edukasi untuk saling menjaga jarak fisik antar individu juga membantu mencegah penyebaran virus covid-19. Jarak yang terbentang antar tubuh atau diri akan mencegah melekatnya virus dari penderita kepada individu sehat.

\section{Permasalahan Mitra}

$\begin{array}{ccr}\text { Situasi } & \text { pandemi } & \text { dengan } \\ \text { mewabahnya } & \text { covid-19 virus } & \text { sangat }\end{array}$ berimbas terhadap kehidupan sosial masyarakat Jaga 8 Perumahan Puri Kelapa Gading, Talawaan, Minahasa Utara. Masyarakat Perum Puri Kelapa Gading secara umum harus mampu menyesuaikan diri dalam menjalani kehidupan pada masa pandemi ini. Protokol kesehatan yang ketat harus dilakukan dalam menjalani aktivitas kehidupan untuk mencegah atau memutus penyebaran virus covid-19. Protokol kesehatan juga harus diterapkan bagi warga dari luar perumahan yang hendak masuk ke dalam perumahan untuk mencegah membawa virus covid-19.

$$
\text { Pengamatan yang dilakukan }
$$
terhadap perilaku masyarakat Jaga 8 Perumahan Puri Kelapa Gading pada selama masa pandemi menunjukkan penerapan protokol kesehatan yang belum maksimal. Masyarakat secara umum masih banyak yang belum disiplin dalam mengenakan masker. Masyarakat masih 
saling berinteraksi atau ngobrol dengan tetangga tanpa menerapkan jarak fisik antar individu. Perilaku sehat seperti rajin mencuci tangan menggunakan sabun juga masih belum optimal dilakukan.

Melalui kegiatan PKM dengan tetap memperhatikan dan menjalankan protokol kesehatan pencegahan penyebaran virus covid-19 ini beberapa permasalahan yang diharapkan dapat ditangani adalah :

1. Pentingnya mengenakan masker secara benar.

2. Pentingnya menjaga jarak fisik antar masyarakat.

3. Pentingnya rajin mencuci tangan menggunakan sabun pada air mengalir.

\section{Tujuan Dan Manfaat Kegiatan}

Kegiatan PKM pada masyarakat Perumahan Puri Kelapa Gading secara umum adalah mampu mencegah penyebaran covid-19 dan terbebas dari infeksi virus yang sangat mematikan tersebut. Secara khusus masyarakat mengetahui pentingnya mengenakan masker secara benar guna mencegah penularan virus melalui droplet dari air liur. Masyarakat juga memahami pentingnya rajin mencuci tangan menggunakan sabun untuk membunuh kuman baik bakteri maupun virus yang terdapat pada tangan. Masyarakat memahami pentingnya menjaga jarak fisik antar individu ketika sedang saling berinteraksi untuk mencegah terpercik droplet dari air liur yang berpotensi membawa virus ketika berbicara.

\section{METODE PELAKSANAAN}

Sasaran PKM secara khusus ditujukan untuk masyarakat Jaga 8 Perumahan Puri Kelapa Gading, Paniki Atas, Talawaan, Minahasa Utara. Secara umum kegiatan PKM ini juga ditujukan bagi masyarakat umum yang hendak berkunjung masuk ke dalam kompleks perumahan. Kegiatan PKM dilaksanakan dengan memperhatikan protokol kesehatan pencegahan penularan covid-19. Kegiatan penyuluhan dilakukan tanpa mengumpulkan masyarakat dalam satu ruangan. Penyuluhan dilakukan dengan memasang spanduk pada berbagai tempat yang cukup strategis di dalam perumahan. Spanduk berisikan himbauan agar masyarakat menerapkan protokol kesehatan. Edukasi cara pemakaian masker yang benar dan pembagian masker juga dilakukan secara door to door atau mengunjungi masyarakat dari rumah ke rumah. Dalam kunjungan kepada masyarakat juga diberikan beberapa selebaran edukasi yang berisikan tata cara pemakaian masker yang baik dan benar. Selebaran edukasi juga berisikan tata cara mencuci tangan yang tepat dan benar.

Edukasi juga diberikan secara khusus kepada tim keamanan yang berjaga di pintu masuk perumahan. Tujuan utama dari edukasi kepada tim keamanan adalah agar mampu membantu menerapkan pelaksanaan protokol kesehatan pencegahan penyebaran covid-19 virus di dalam perumahan. Peran tim keamanan juga sangat penting untuk meningatkan bagi warga yang hendak memasuki perumahan agar mengenakan masker, mencuci tangan terlebih dahulu dan pengecekan suhu tubuh.

Penegakkan pelaksanaan protokol kesehatan dalam rangka mencegah penyebaran covid-19 virus dengan bantuan tim keamanan perumahan. Peran tim keamanan perumahan adalah mengingatkan kepada masyarakat untuk mengenakan masker ketika melakukan kegiatan di luar rumah.

Evaluasi keberhasilan kegiatan dilakukan dengan mengamati perilaku masyarakat Perumahan Puri Kelapa Gading dalam menjalankan protokol kesehatan secara tepat dan benar. Evaluasi dilakukan dengan melihat masyarakat yang mengenakan masker ketika hendak memasuki gerbang perumahan. Sampel masyarakat yang diamati sebanyak 50 masyarakat per minggu selama 4 minggu setelah edukasi dilakukan. Parameter yang diamati adalah mengenakan masker dengan baik dan benar.

\section{HASIL DAN PEMBAHASAN}

Kegiatan pengabdian kepada masyarakat ini dilaksanakan selama bulan Mei dan Juni 2020. Kegiatan dilakukan terhadap masyarakat yang tinggal pada 
wilayah Lingkungan Jaga 8 Perumahan Puri Kelapa Gading, Desa Paniki Atas, Kecamatan Talawaan dan Kabupaten Minahasa Utara, Sulawesi Utara. Kegiatan penyuluhan dilakukan tanpa mengumpulkan warga melainkan melalui media spanduk dan kunjungan dari rumah ke rumah. Kegiatan dari rumah ke rumah dilakukan untuk membagikan masker serta edukasi cara mengenakan masker yang baik dan benar.

Kegiatan penyuluhan penerapan protokol kesehatan pencegahan penyebaran virus covid-19 dilakukan dengan memasang spanduk himbauan. Spanduk berisikan himbauan agar masyarakat yang hendak memasuki komplek perumahan wajib memakai masker, mencuci tangan (Gambar 1). Spanduk yang dipasang pada pos masuk atau gerbang perumahan agar masyarakat yang hendak masuk ke dalam perumahan mengenakan masker dan mencuci tangan terlebih dahulu.

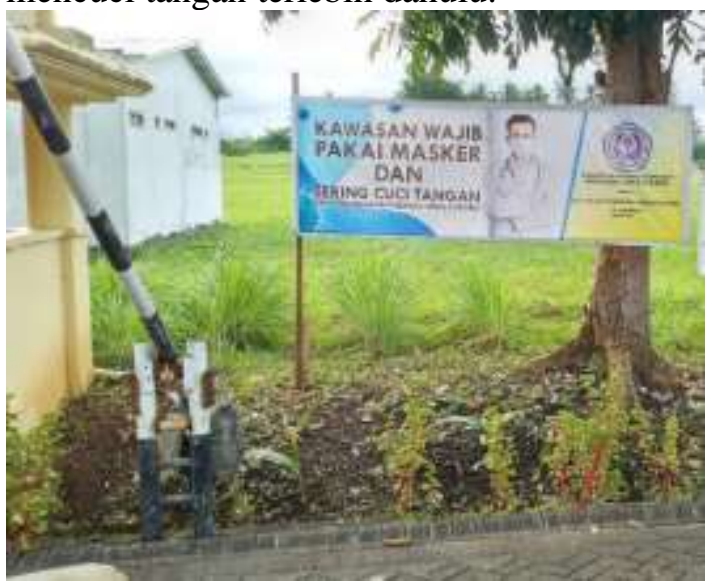

Gambar 1. Spanduk wajib mengenakan masker yang dipasang pada pintu gerbang perumahan

Spanduk penyuluhan yang berisikan himbauan untuk menjaga kesehatan diri sendiri maupun keluarga dari infeksi virus covid-19. Himbauan menjaga kesehatan dari infeksi virus covid-19 pada spanduk dengan cara mengenakan masker, mencuci tangan dan menjaga jarak. Spanduk penyuluhan pencegahan penyebaran virus covid-19 dipasang pada beberapa tempat di dalam komplekS perumahan. Tempat pemasangan spanduk penyuluhan pada berbagai tempat strategis yang mudah terbaca oleh warga masyarakat (Gambar 2).

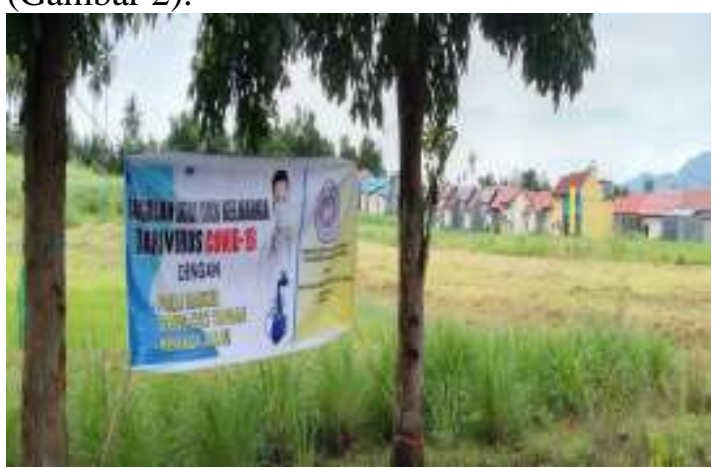

Gambar 2. Spanduk himbauan menjaga diri dari virus covid-19 19

Penyuluhan pengunaan masker dan pembagian masker dilakukan dengan cara melakukan kunjungan dari rumah ke rumah. Kegiatan dari rumah ke rumah dilakukan untuk mencegah terjadinya kerumunan massa yang dapat memicu penyebaran virus. Edukasi cara pengunaan masker yang benar sangat penting bagi masyarakat agar tepat dalam mengenakan masker (Gambar 3). Pemberian masker juga diharapkan mampu menumbuhkan kesadaran masyarakat dalam disiplin mengenakan masker. Selain kunjungan dari rumah ke rumah juga bantuan masker diserahkan kepada kepala lingkungan memiliki jadwal kunjungan terhadap warga dalam tugasnya sebagai pelayan masyarakat.

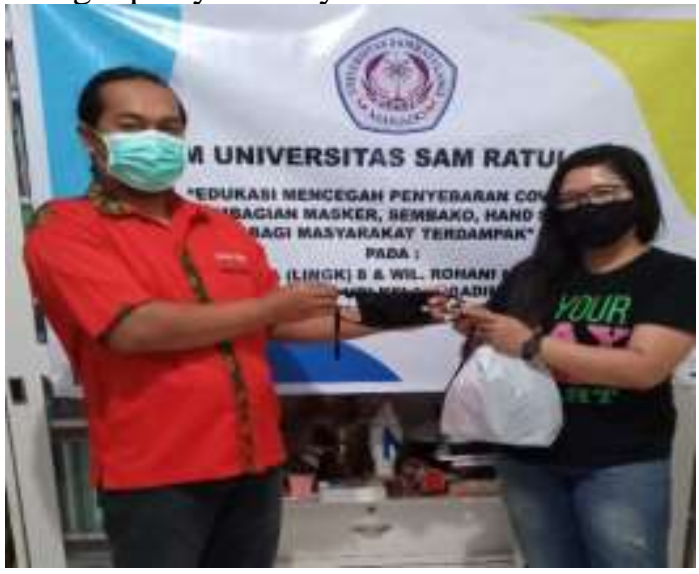

Gambar 3. Proses edukasi cara mengenakan masker kepada masyarakat

Kegiatan pengabdian khususnya penyuluhan juga dilakukan kepada tim keamanan perumahan untuk membantu tercapainya tujuan penerapan protokol 
kesehatan dalam rangka pencegahan penyebaran virus covid-19. Tim keamanan juga diharapkan mampu mendisiplinkan warga yang akan memasuki gerbang perumahan agar mengenakan masker dan mencuci tangan terlebih dahulu. Tim keamanan juga memiliki kewenangan untuk menegur warga perumahan yang melakukan aktivitas sosial tanpa menjaga jarak. Pada penyuluhan kepada tim keamanan juga diberikan bantuan berupa sabun cuci tangan agar dapat digunakan bagi masyarakat yang hendak memasuki area komplek perumahan (Gambar 4).

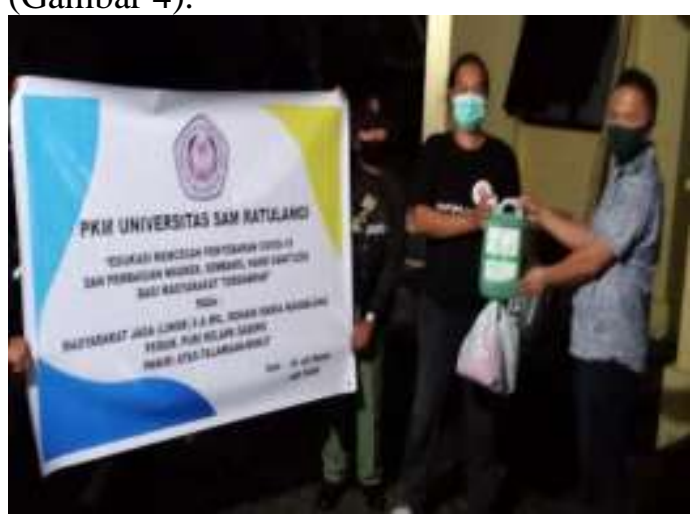

Gambar 4. Pemaberian bantuan sabun cuci tangan dan masker kepada tim keamanan

Evaluasi kegiatan hasil dari edukasi mengenai pentingnya mengenakan masker dengan baik dan benar tersaji pada Gambar 5. Sebelum edukasi diperoleh data masyarakat yang mengendarai mobil dari 50 sampel per minggu diperoleh 25 masyarakat yang mengenakan masker dengan baik. Setelah edukasi pada minggu ke-1 diperoleh 42 masyarakat telah mengenakan masker dengan baik dan benar. Pada minggu ke-2, ke-3 dan ke-4 setelah edukasi diperoleh jumlah masyarakat yang mengenakan masker sebanyak 42, 40, 45 dan 42 orang. Pada minggu ke-4 terdapat peningkatan sebesar $68 \%$ masyarakat yang mengendarai mobil dalam mengenakan masker secara baik dan benar dibandingkan sebelum dilakukan edukasi dengan jumlah $84 \%$ dari total sampel.

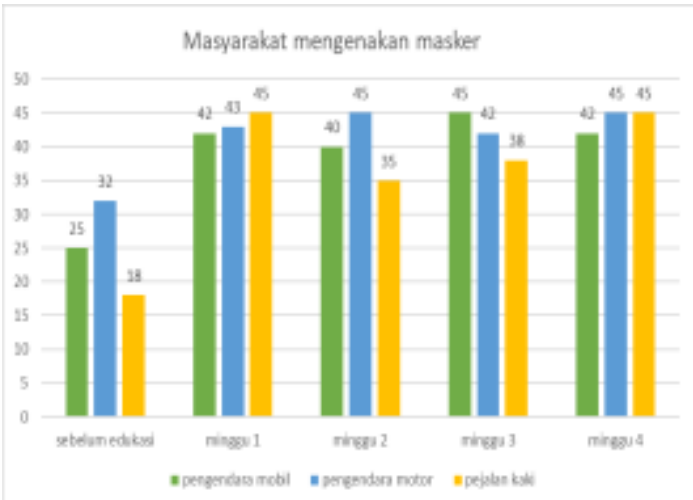

Gambar 5. Jumlah masyarakat yang mengenakan masker sebelum dan setelah dilakukan edukasi (KIE)

Masyarakat yang mengendarai sepeda motor sebelum edukasi (KIE) terdapat 32 yang telah mengenakan masker dengan baik dan benar. Sesudah edukasi meningkat menjadi 45 pada minggu ke-4 atau meningkat sebesar $40 \%$. Total jumlah masyarakat yang mengendarai motor sebesar 90\% telah mengenakan masker secara tepat setelah memperoleh edukasi KIE.

Masyarakat yang berjalan kaki sebelum edukasi hanya $36 \%$ yang mengenakan masker atau hanya 18 orang dari 50 sampel. Setelah edukasi KIE, total masyarakat pada minggu ke-1, ke-2, ke-3 dan ke-4 yang telah mengenakan masker sebanyak 45, 35, 38 dan 45 orang. Pada minggu ke-4 terdapat peningkatan masyarakat pejalan kaki yang mengenakan masker sebesar $150 \%$ menjadi 45 orang atau $90 \%$ dari total sampel.

\section{KESIMPULAN DAN SARAN Kesimpulan}

Edukasi dan himbauan untuk tetap menjalankan protokol kesehatan dalam upaya mencegah penyebaran virus covid-19 sangat penting dan bermanfaat. Edukasi dan himbauan akan membentuk kebiasaan masyarakat untuk berperilaku hidup sehat dengan tetap mengenakan masker, rajin mencuci tangan dan menjaga jarak ketika melakukan aktivitas sosial.

Edukasi tata cara penggunaan masker yang tepat dan benar sangat membantu masyarakat dalam mengenakan 
masker yang dapat membantu mencegah penyebaran virus covid-19. Edukasi tata cara mencuci tangan dengan sabun dan air mengalir juga membantu masyarakat untuk tahu cara mencuci tangan yang tepat dalam mencegah penyebaran virus covid-19. Edukasi untuk menjaga jarak fisik ketika berinteraksi dengan sesama juga memberikan pengetahuan akan jarak yang aman agar tidak terpapar virus yang terbawa dari droplet cairan tubuh.

\section{Saran}

Program edukasi dan anjuran untuk melaksanakan protokol kesehatan dalam mencegah penyebaran virus covid-19 harus terus digalakkan hingga masa pandemi berakhir. Pimpinan daerah tempat tinggal seperti kepala lingkungan dan ketua wilayah rohani diharapkan untuk tetap mengingatkan warga agar tetap menggunakan masker, rajin mencuci tangan dan menjaga jarak fisik ketika beraktivitas.

\section{UCAPAN TERIMAKASIH}

Terimakasih kepada Kementerian Pendidikan Dan Kebudayaan Republik Indonesia, Rektor Universitas Sam Ratulangi dan Ketua Lembaga Penelitian dan Pengabdian Kepada Masyarakat UNSRAT, atas pembiayaan kegiatan melalui SKIM PKM dana PNBP UNSRAT 2020. Terimakasih juga disampaikan kepada Kepala Lingkungan Jaga 8 dan Ketua Wilayah Rohani Santa Maria Magdalena serta tim keamanan Perumahan Puri Kelapa Gading, Paniki Atas, Talawaan, Minahasa Utara yang tetap menjalankan protokol kesehatan dalam rangka mencegah penyebaran virus covid-19.

\section{DAFTAR PUSTAKA}

Chen, H., Guo, J., Wang, C., Luo, F., Yu, X., Zhang, W., ... \& Liao, J. 2020. Clinical characteristics and intrauterine vertical transmission potential of COVID-19 infection in nine pregnant women: a retrospective review of medical records. The Lancet, 395(10226), 809-815

Telaumbanua, D. 2020. Urgensi Pembentukan Aturan Terkait Pencegahan Covid-19 di Indonesia. Qalamuna - Jurnal Pendidikan, Sosial, dan Agama. 12(1) : 59-70.

Yunus, N.R dan Rezki, A. 2020. Kebijakan Pemberlakuan Lockdown Sebagai Antisipasi Penyebaran Covid-19 Virus Covid-19. SALAM-Jurnal Sosial \& Budaya Syar-i. 7(3) : 227238.

Huang, C. Wang, Y. Li, X. 2020. Clinical features of patients infected with 2019 novel covid-19virus in Wuhan, China. Lancet. 395: 497506.

Singhal, T. (2020). A Review of Covid19virus Disease-2019 (COVID-19). The Indian Journal of Pediatrics, 87(4): 281-286.

Zukmadini, A.Y., Karyadi, B., \& Kasrina, K. 2020. Edukasi Perilaku Hidup Bersih dan Sehat (PHBS) dalam Pencegahan COVID-19 Kepada Anak-Anak di Panti Asuhan. Jurnal Pengabdian Magister Pendidikan IPA, 3(1). doi: https://doi.org/10.29303/jpmpi.v3i1 .440

Mona, N. 2020. Konsep Isolasi Dalam Jaringan Sosial Untuk Meminimalisasi Efek Contagious (Kasus Penyebaran Virus Covid-19 Di Indonesia). Jurnal Sosial Humaniora Terapan, 2(2): 117-125.

Razi F., Yulianty V., Amani, S A., Fauzia J H. 2020. Bunga Rampai COVID19: Buku Kesehatan Mandiri untuk Sahabat. PD Prokami: Depok. 